\title{
REVIEW
}

\section{The role of RFamide peptides in feeding}

\author{
David A Bechtold and Simon M Luckman
}

Faculty of Life Sciences, University of Manchester, 1.124 Stopford Building, Oxford Road, Manchester M13 9PT, UK

(Requests for offprints should be addressed to D A Bechtold; Email: david.bechtold@manchester.ac.uk)

\begin{abstract}
In the three decades since FMRFamide was isolated from the clam Macrocallista nimbosa, the list of RFamide peptides has been steadily growing. These peptides occur widely across the animal kingdom, including five groups of RFamide peptides identified in mammals. Although there is tremendous diversity in structure and biological activity in the RFamides, the involvement of these peptides in the regulation of energy balance and feeding behaviour appears consistently through
\end{abstract}

evolution. Even so, questions remain as to whether feedingrelated actions represent a primary function of the RFamides, especially within mammals. However, as we will discuss here, the study of RFamide function is rapidly expanding and with it so is our understanding of how these peptides can influence food intake directly as well as related aspects of feeding behaviour and energy expenditure.

Journal of Endocrinology (2007) 192, 3-15

\section{Introduction}

The first recognised member of the RFamide neuropeptide family was the cardioexcitatory peptide, FMRFamide, isolated from ganglia of the clam Macrocallista nimbosa (Price \& Greenberg 1977). Since then a large number of these peptides, defined by their carboxy-terminal arginine (R) and amidated phenylalanine (F) residues (hence RFamide), have been identified in the nervous systems of animals within all major phyla. Vertebrates and more especially invertebrates can each express an array of RFamide peptides, owing to the fact that multiple genes encoding RFamides are often present in a single species, and multiple mature RFamide peptides can be generated by a single polypeptide precursor. The prevalence of RFamides in invertebrates is illustrated by the nematode Caenorhabditis elegans, in which 22 known genes encoding RFamide peptides (referred to as $f p$ genes) and 59 distinct RFamide peptides have been identified (Li et al. 1999). Impressively, $f p$ gene products are expressed in almost half of the 302 neurons found in the adult nematode (Li et al. 1999, Kim \& Li 2004).

RFamide peptides show a remarkable diversity in $\mathrm{N}$-terminal sequence, and as a likely consequence, a broad pattern of biological activities. Pharmacological studies have implicated RFamide peptides in roles that include cardiovascular function, modulation of muscle contraction, control of locomotor activity, water balance, neuroendocrine and neuromodulatory activities (Dockray 2004, Sun et al. 2005, Fukusumi et al. 2006). As with most neuropeptides, the RFamides are often co-localised with classical neurotransmitters, including acetylcholine, serotonin and gamma-amino bulyric acid (GABA).

Although a role for RFamides in feeding behaviour was first suggested over 20 years ago, when FMRFamide was shown to be anorexigenic in mice (Kavaliers et al. 1985), the question of whether regulating food intake represents a primary function of RFamide signalling remains. One convincing piece of evidence is that RFamide involvement in feeding behaviour has been demonstrated across a wide range of animal classes, including coelenterates, molluscs, amphibians, birds and mammals (see below), suggesting that this function has been conserved through evolution (Dockray 2004). Here, we review the evidence that explores the ability of RFamide peptides to influence feeding behaviour in both mammalian and non-mammalian species.

\section{Mammalian RFamide peptides}

Immunoreactive staining of vertebrate tissues with antibodies raised against the molluscan FMRFamide peptide first suggested that the RFamide peptides were to be found in higher animal groups (Boer et al. 1980, Dockray et al. 1981, Weber et al. 1981). Soon after, LPLRFamide was purified from chicken brain (Dockray et al. 1983) and since then the list of vertebrate RFamides has grown steadily, including five genes encoding RFamide peptides identified in mammals (Table 1; Fig. 1). In addition to the increasing number of peptides, several G-protein-coupled receptors (GPRs) are now recognised as receptors for the mammalian RFamides. 
Table 1 Primary sequences of RFamide peptides

\section{Species}

\section{RFamide peptide}

FMRFamide

NPFF

NPAF

PrRP20

PrRP31

C-RFa

LPLRFamide

RFRP-1

RFRP-3

$\mathrm{GnIH}$

Metastin

QRFP

26RFa
Clam

Human

Human

Human

Human

Carp

Chicken

Bovine

Bovine

Quail

Human

Human

Frog

\section{Sequence}

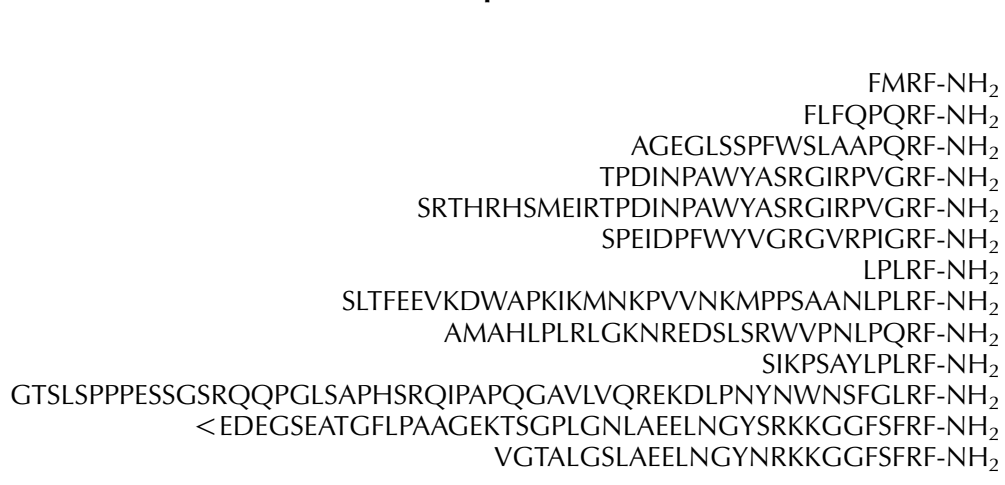

Pyroglutamic acid is shown as $<\mathrm{E}$.

\section{NPFF family}

Neuropeptide FF (NPFF, shortened from F8Famide) and neuropeptide AF (NPAF, from A18F) were isolated originally from bovine brain by affinity purification using antibodies raised against FMRFamide (Yang et al. 1985). The two peptides are derived from the same gene and precursor peptide, and their expression has been demonstrated in the brains of several mammalian species (Perry et al. 1997, Vilim

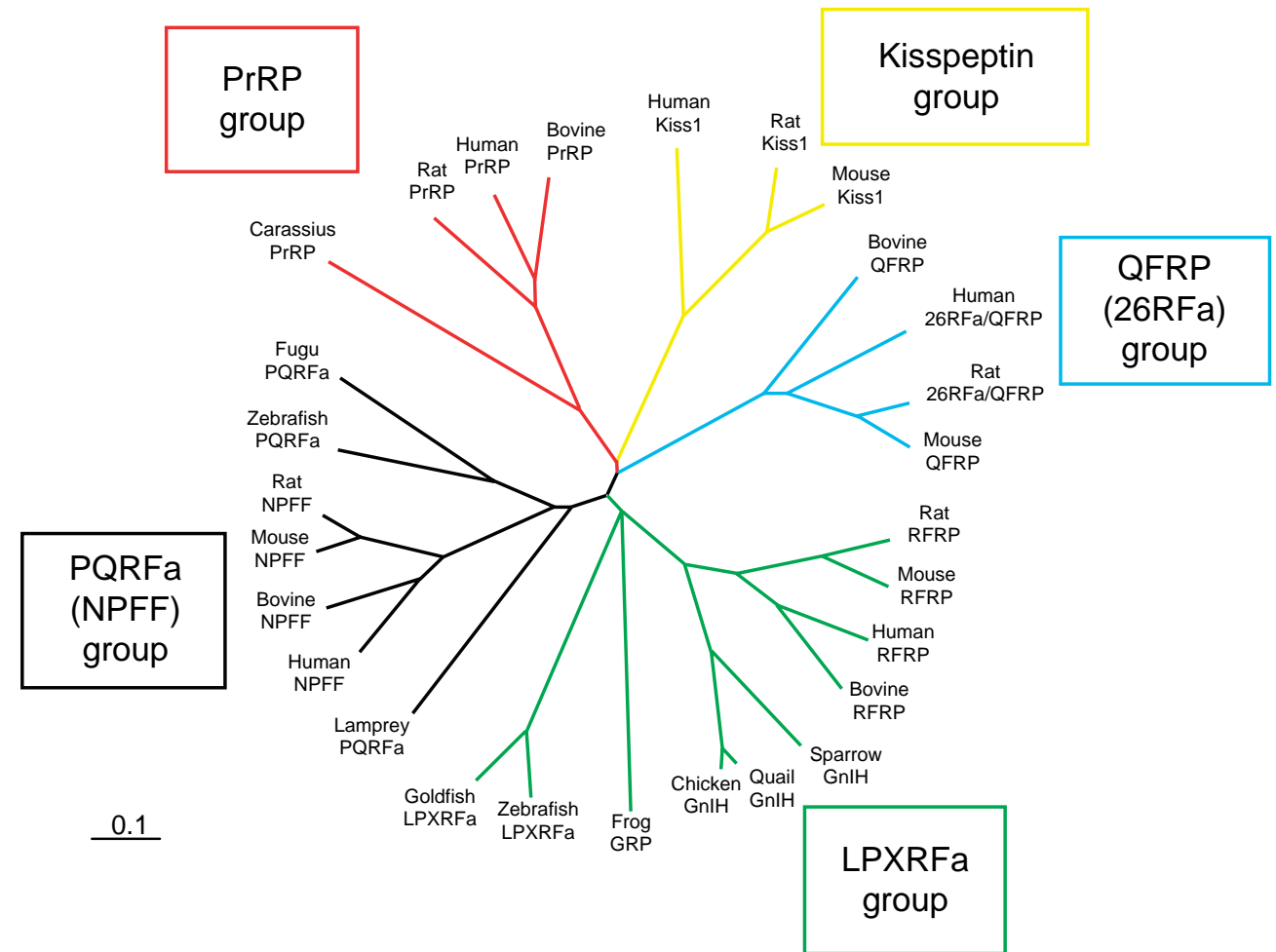

Figure 1 Unrooted phylogenetic tree of the identified and the putative RFamide peptides in mammals and other vertebrates. The neighbour-joining method was used to construct this phylogenetic tree. Data were re-sampled by 1000 bootstrap replicates to determine the confidence indices within the phylogenetic tree. Scale bar refers to a phylogenetic distance of 0.1 amino acid substitutions per site. Frog 26 RFa does not appear on the map and non-mammalian homologues of kisspeptin have not yet been identified. However, receptors related to GPR54 and GPR103 have been predicted from the zebrafish and chicken genomes respectively. Figure reprinted with minor modification from Osugi et al. (2006), FEBS Journal 273; copyright, with permission from Blackwell-Synergy. 
et al. 1999, and references cited below). The bestdocumented function of NPFF is its ability to modulate opioid-induced analgesia (Yang et al. 1985, Panula et al. 1999, Dong et al. 2001), although cardiovascular (Allard et al. 1995) and feeding (Murase et al. 1996, Sunter et al. 2001, Bechtold \& Luckman 2006) effects have also clearly been demonstrated.

Two GPRs have been identified as putative receptors for NPFF and consequently designated NPFF1 and NPFF2 (Bonini et al. 2000). Subsequent studies have shown that NPFF1 exhibits a higher affinity for RFRP than for NPFF, and NPFF displays a higher potency for NPFF2 (Liu et al. 2001, Yoshida et al. 2003). Therefore, NPFF2 is now generally considered the endogenous receptor for NPFF, with NPFF1 as the RFRP receptor. However, NPFF2 appears to be fairly promiscuous, showing relatively high affinities for NPFF, RFRPs as well as prolactin-releasing peptide (PrRP; Engstrom et al. 2003). Human NPFF1 and NPFF2 share 46\% sequence identity and exhibit 31-37\% identities with the receptors for orexin, neuropeptide Y, $\mathrm{CCK}_{1}$ and PrRP.

The major population of NPFF-expressing neurons in the rat brain lies within the nucleus of the tractus solitarius (NTS; Kivipelto et al. 1989, Boersma et al. 1993, Lee et al. 1993, Vilim et al. 1999) and projects to the ventral lateral medulla (VLM), lateral parabrachial nucleus (IPBN) and paraventricular nucleus of the hypothalamus (PVN; Jhamandas et al. 2001, Goncharuk et al. 2006). NPFF-expressing neurons have also been reported in the vicinity of the ventromedial (VMN) and dorsomedial (DMN) nuclei of the hypothalamus. However, the lack of mRNA expression in this region (Vilim et al. 1999) suggests that the immunostaining may be due to cross-reactivity of antibodies with other related RFamide peptides (such as RFRP) which have been reported in the region (Hinuma et al. 2000). While NPFF immunoreactive fibres have a fairly wide distribution in the rat brain, major targets include the PVN, the $1 \mathrm{PBN}$ and the VLM, as all the three areas exhibit dense NPFF-containing nerve fibres, NPFF receptor expression and NPFF-binding activity (Kivipelto et al. 1989, Boersma et al. 1993, Vilim et al. 1999, Hinuma et al. 2000, Liu et al. 2001, Gouarderes et al. 2002, 2004a, Goncharuk et al. 2006). PVN neurons have also been shown to be electrically responsive to NPFF (Jhamandas et al. 2006) and express the immediate early gene, c-fos, following intracerebroventricular (ICV) injection of the peptide (Jhamandas \& MacTavish 2003). In line with its role in nociception, NPFF and NPFF2 are expressed in dorsal horn of the spinal cord (Panula et al. 1996, Vilim et al. 1999, Gouarderes et al. 2002). It is important to point out that pronounced inter-species and inter-strain differences have been reported for the localisation of NPFF and its receptors (Boersma et al. 1993, Gouarderes et al. 2002, 2004b).

The ability of NPFF to influence feeding behaviour has been demonstrated in rats and mice. Specifically, NPFF injected into the cerebral ventricles inhibits short-term food intake in rats (Murase et al. 1996, Sunter et al. 2001) and in both pre-fasted and ad libitum fed mice (Bechtold \& Luckman
2006). Sunter et al. (2001) have reported that the attenuation of feeding in rats by NPFF is accompanied by an acute stimulation of water intake; we have not observed this effect in mice (unpublished results). As described above, both NPFF and its receptors are localised in the hypothalamus, consistent with a direct action of NPFF on hypothalamic neurons regulating food intake. NPFF immunoreactive fibres densely innervate another area implicated in feeding behaviour, the PBN. Administration of NPFF into the PBN in relatively low doses $(<10 \mathrm{nmol})$ can inhibit the stimulation of food intake in response to the $\mu$-opioid receptor agonist, [D-Ala, N-MePhe, Gly-oL]-enkephalin (DAMGO; Nicklous \& Simansky 2003). Interestingly, higher doses of NPFF caused an increase in food intake which could be blocked by naloxone, an opioid receptor antagonist. Combined with the well-documented ability of NPFF to modulate opioid-induced analgesia (Panula et al. 1999), these findings suggest that the modulation of feeding behaviour by NPFF and opioids involve similar pathways (Murase et al. 1996). NPFF has been shown to depress excitatory glutamatergic synaptic transmission in PBN neurons, evidently acting via pre-synaptic $\delta$-opioid receptors (Chen et al. 2000). However, NPFF shows no affinity for opioid receptors (Raffa et al. 1994, Gouarderes et al. 1998), but may indirectly modify opioid receptor activity. For example, in vivo intrathecal infusion of an NPFF analogue enhances met-enkephalin release from the rat spinal cord (Ballet et al. 1999).

Since most of the studies relating to the feeding effects of NPFF are pharmacologically based (i.e., injection of exogenous peptide), it is difficult to establish whether NPFF or its receptors play a physiological role in regulating feeding behaviour. Unpublished results from our laboratory suggest that NPFF is unlikely to act as an endogenous satiety signal. ICV administration of NPFF to pre-fasted mice leads to a disruption of the behavioural satiety sequence, especially at the onset of re-feeding, rather than shortening the crossover point from feeding to rest (taken as a measure of satiety), suggesting that NPFF inhibits feeding rather than enhances satiety. Furthermore, NPFF neurons within the NTS are not activated by the endogenous satiety factor, cholecystokinin (CCK). The expression of NPFF2 mRNA is not altered by diet restriction or in diet-induced obese rats (Laemmle et al. 2003). However, ICV administration of NPFF has been shown to activate oxytocin neurons in the PVN (Jhamandas \& MacTavish 2003). Therefore, the anorexic effects of ICV NPFF may involve oxytocin, as this peptide can also reduce feeding when administered centrally (Arletti et al. 1990, Olson et al. 1991).

\section{$\operatorname{PrRP}$ family}

Two PrRP peptides (PrRP-20 and PrRP-31) were isolated originally from bovine hypothalamus and so named because of their ability to induce prolactin release from dissociated rat pituitary cells (Hinuma et al. 1998). It now appears unlikely 
that PrRP stimulates prolactin release in vivo (Taylor \& Samson 2001), despite there being evidence that PrRP is involved in regulating the secretion of other hypothalamopituitary factors, including corticotrophin-releasing hormone, follicle-stimulating hormone (FSH) and luteinising hormone (LH), and oxytocin (Maruyama et al. 1999b, Hizume et al. 2000, Matsumoto et al. 2000, Samson et al. 2003).

A number of observations by our group and others strongly implicate PrRP in the homeostatic regulation of feeding and energy balance. In the rat brain, PrRP mRNA is downregulated in states of negative energy balance (fasting and lactation; Lawrence et al. 2000), and central administration of PrRP decreases feeding and body weight gain in rats and mice (Lawrence et al. 2000, 2002, Bechtold \& Luckman 2006). The anorexic actions of PrRP appear to be related to satiety, as administration of the peptide does not invoke a conditioned taste aversion, or disrupt the normal behavioural satiety sequence (Lawrence et al. 2002). The anorexic actions of PrRP are attenuated in mice (Bechtold \& Luckman 2006) and rats (Watanabe et al. 2005) that lack functional expression of GPR10, the putative receptor for PrRP. The significance of endogenous PrRP-GPR10 signalling in the regulation of feeding behaviour is also demonstrated by the fact that GPR10-knockout mice become heavier than congenetic wild types, due primarily to an increased accumulation of fat stores (Gu et al. 2004). The recent demonstration that a GPR10 gene mutation is the primary cause of the obese phenotype in the Otsuka Long-Evans Tokushima Fatty rat further iterates the significance of this signalling pathway in energy homeostasis (Okuno et al. 2001, Watanabe et al. 2004).

In the rat, the majority of PrRP-expressing neurons reside in the brainstem within the NTS and the VLM (Roland et al. 1999, Ibata et al. 2000, Lee et al. 2000). A smaller population of PrRP-expressing neurons also reside in the hypothalamic DMN. The NTS and VLM are regions that receive extensive gastrointestinal and autonomic vagal inputs, and it is established that gut-produced CCK inhibits food intake via activation of vagal afferent neurons that terminate in the NTS (Saper 2004). Central administration of PrRP elicits a similar pattern of neuronal c-fos expression as that observed following the peripheral administration of CCK (Lawrence et al. 2002, Bechtold \& Luckman 2006). The PrRP neurons localised to the NTS and the VLM are also activated by CCK, suggesting that PrRP signalling may be important in relaying peripheral satiety signals, such as CCK, to brain feeding centres (Luckman \& Lawrence 2003).

GPR10 mRNA and PrRP-binding activity are present within the dorsal vagal complex of the medulla (Roland et al.
1999, Ibata et al. 2000, Lee et al. 2000, Ellacott et al. 2005) and so PrRP may act to regulate vago-vagal reflexes. Direct injection of PrRP into the dorsal motor nucleus of the vagus can alter gastric motor function by the presynaptic modulation of glutamatergic neurones (Grabauskas et al. 2004). However, PrRP-immunoreactive fibres and GPR10 mRNA expression have been demonstrated also in a number of hypothalamic nuclei (Fujii et al. 1999, Roland et al. 1999, Maruyama et al. 1999a, Ibata et al. 2000, Lee et al. 2000). The suggestion that the brainstem PrRP neurons serve to relay satiety signals is supported by the finding that GPR10-knockout mice do not reduce feeding in response to peripherally administered CCK (Fig. 2; Bechtold \& Luckman 2006).

Pair-feeding studies suggest that reduced weight gain in rats treated with PrRP is not accounted for solely by a reduction in food intake (Lawrence et al. 2000, 2004). The maintenance of proper energy balance involves regulating both energy intake and energy expenditure. Generally, compounds that inhibit energy intake also cause an increase in energy expenditure and, conversely, stimulation of energy intake is linked to decreased energy expenditure and weight gain (Schwartz et al. 2000). Indeed, PrRP administration increases both body temperature and $\mathrm{O}_{2}$ consumption in rats (Lawrence et al. 2004), providing direct evidence for a role of PrRP in modulating not only feeding behaviour, but also energy expenditure. Furthermore, GPR10-knockout mice exhibit a much lower basal metabolic rate, when compared with wild-type mice (our unpublished observations), which likely contributes to the development of obesity in these animals (Gu et al. 2004).

Within the VLM and NTS, PrRP co-localises with noradrenaline in the A1 and A2 neuronal populations respectively (Chen et al. 1999, Roland et al. 1999). These noradrenergic neurons are known to mediate stress-related responses, suggesting a role for PrRP in stress. In line with this possibility, models of emotional stress, including conditionedfear stimuli and water immersion/restraint stress activate both medullary and hypothalamic PrRP neurons (Maruyama et al. 2001). The medullary neurons are also activated by nociceptive stimuli including foot shock (Morales \& Sawchenko 2003). Furthermore, the expression of PrRP mRNA in the NTS and VLM is up-regulated by restraint stress or formalin injection (Mera et al. 2006). Like PrRP, stressful stimuli evoke increases in blood pressure and alter feeding behaviour, making it tempting to speculate that PrRP neurons may regulate feeding in times of stress. Similar to the actions of NPFF, anti-nociceptive actions of PrRP have been demonstrated. Specifically, injection of PrRP into the NTS

Figure 2 (A) PrRP (2 nmol) significantly reduces food intake in pre-fasted GPR10 +/ + mice compared with mice treated with vehicle, but had no measurable effect on mice lacking GPR10. (B) NPFF (4 nmol) caused a significant reduction in feeding in both wild-type and knockout mice. (C) Administration of CCK caused a dose-dependent reduction in food intake over the first hour of nocturnal feeding in GPR10 $+/+$ mice, but had no significant effect on GPR10-/- mice. ${ }^{*} P<0 \cdot 05,{ }^{\dagger} P<0 \cdot 01$ and ${ }^{\ddagger} P<0 \cdot 001$, two-way ANOVA with Bonferroni's post hoc test. Figure reproduced with minor modifications from Bechtold \& Luckman (2006), Endocrinology 147; copyright, with permission from The Endocrine Society. 


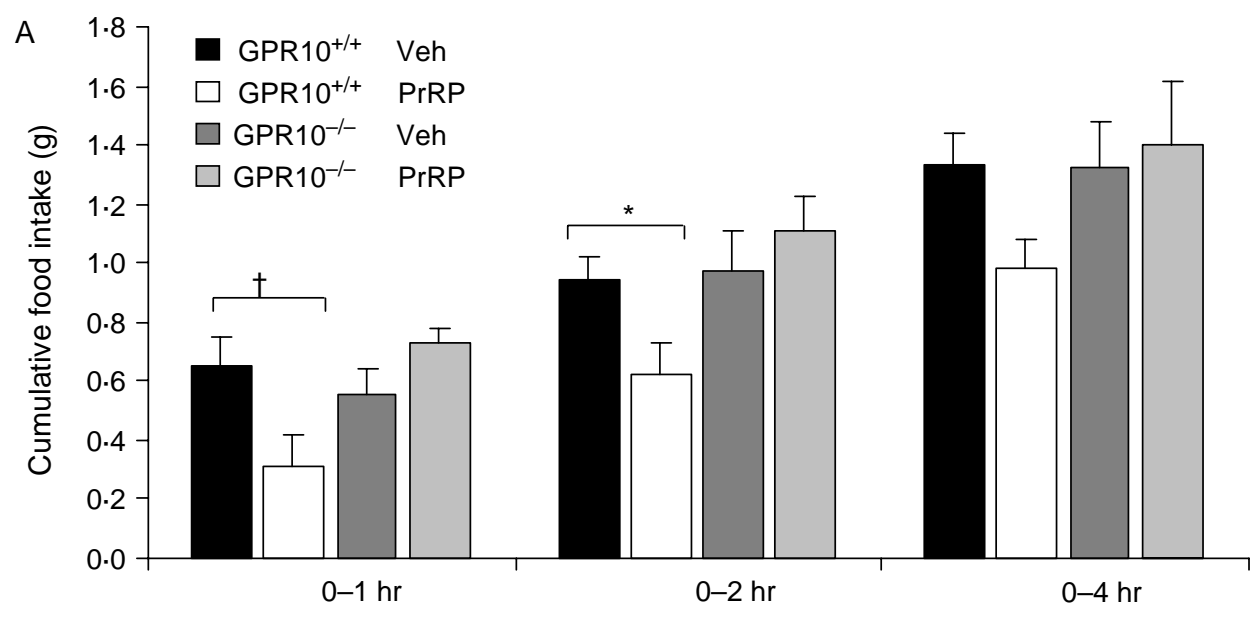

Time post-injection
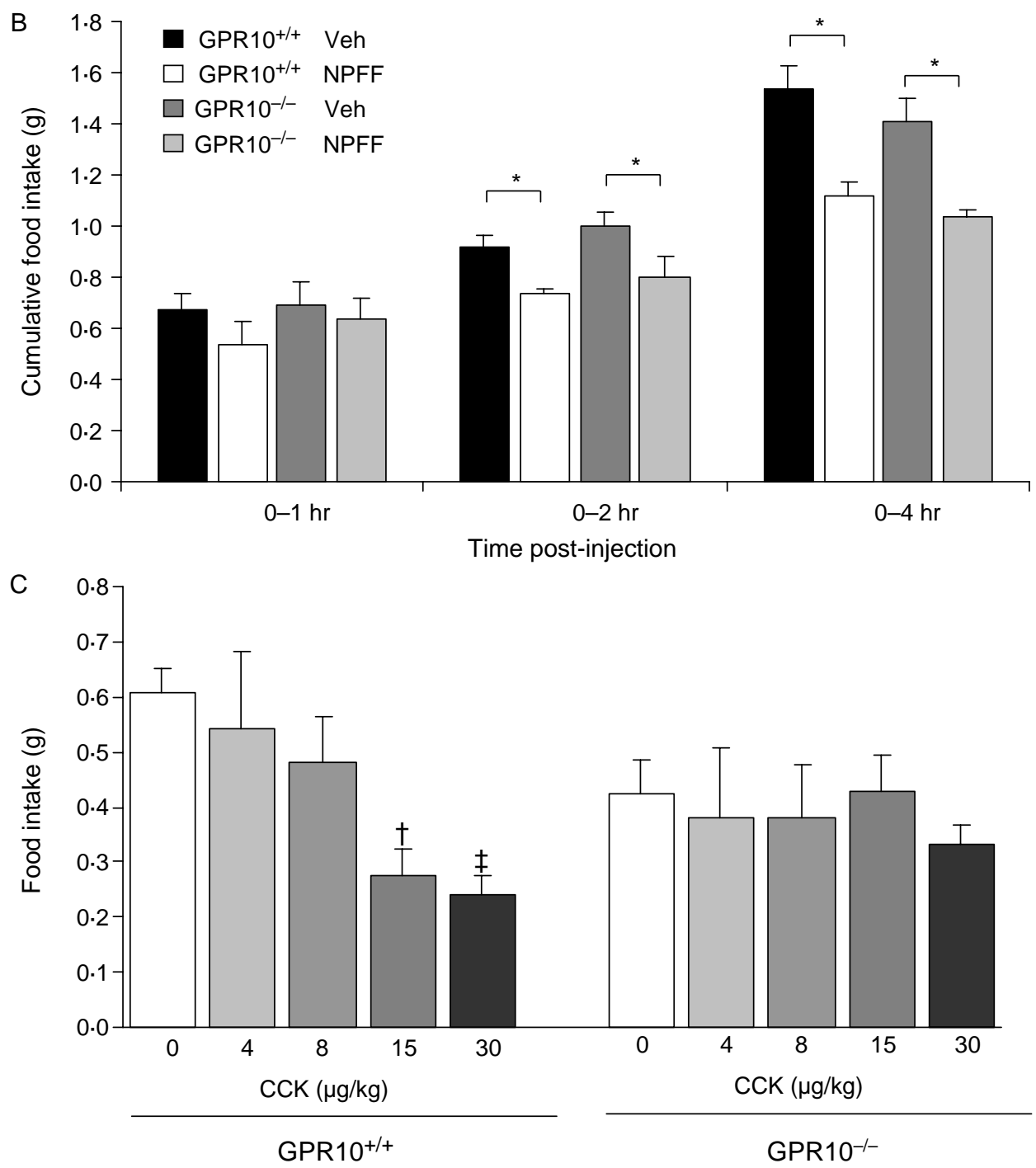
reduces the sensitivity of normal rats to mechanical pressure (paw pinch; Kalliomaki et al. 2004). Furthermore, mice lacking GPR10 exhibit higher nociceptive thresholds and stronger stress-induced analgesia than wild-type mice (Laurent et al. 2005).

Fish and chicken orthologues to mammalian PrRP have been identified (Moriyama et al. 2002, Seale et al. 2002, Tachibana et al. 2005). ICV administration of rat PrRP can stimulate feeding and reduce body temperature in chicks (Tachibana et al. 2004), the opposite effect to that observed in rats and mice. This contrast between chicks and mammals has also been reported for ghrelin and growth hormone-releasing hormone, both of which inhibit feeding in chicks, yet stimulate it in rats (Vaccarino et al. 1985, Furuse et al. 2001, Nakazato et al. 2001). In goldfish, hypothalamic PrRP mRNA expression is modified by feeding status, and either intraperitoneal or ICV administration of fish PrRP peptide has been shown to suppress food intake (Kelly \& Peter 2006). It is therefore important to keep in mind that while an evolutionarily conserved role of RFamides in the regulation of feeding behaviour seems clear, the specific actions can vary greatly between class and species.

\section{LPXR Famide family}

The mammalian members of the LPXRFamide peptide family are RFRP-1 and -3 (from RFamide Related Peptides; Hinuma et al. 2000, Fukusumi et al. 2001, Yoshida et al. 2003). RFRP-1 and -3 share a similar C-terminal sequence with NPFF (Table 1) and as discussed above RFRP analogues bind with relatively high affinity to the NPFF1 and NPFF2 receptors (Hinuma et al. 2000, Liu et al. 2001, Engstrom et al. 2003, Yoshida et al. 2003), first identified as cognate receptors for NPFF (Bonini et al. 2000). NPFF1 exhibits a higher affinity for RFRP-1 and -3 than for NPFF and is now considered to be the endogenous RFRP receptor (Hinuma et al. 2000, Engstrom et al. 2003).

In the mouse brain, the major populations of RFRPexpressing neurons have been demonstrated in the DMN, the lateral superior olive and the NTS, with dense RFRPimmunoreactive fibres observed in the PVN, the IPBN, the NTS and the lateral reticular nucleus, as well as lamina I and II in the dorsal horn of the spinal cord (Ukena \& Tsutsui 2001). Studies of the rat brain imply that neurons expressing RFRP1 and -3 are limited to the caudal portion of the hypothalamus, namely the periventricular nucleus (PeVN), and an area between the VMN and the DMN (Hinuma et al. 2000, Fukusumi et al. 2001, Yano et al. 2003), although it is unclear from these reports whether RFRP-expressing neurons can be found elsewhere. As with the mouse, RFRP immunoreactive nerve fibres are widespread in the rat brain, but notably include the hypothalamic PVN, the supraoptic nucleus (SON) and the external layer of the dorsal horn (Fukusumi et al. 2001, Yano et al. 2003). ICV administration of the RFRPs induce the expression of $c-f o s$ in a number of areas, including the anterior NTS, the locus coeruleus, SON, PeVN and the arcuate nucleus of the hypothalamus (Yano et al. 2003). A prominent hypothalamic expression of LPXRFamide peptides has also been demonstrated in birds and other vertebrates. LPXRFamide neurons are localised to the PVN in the quail and sparrow (Tsutsui et al. 2000, Bentley et al. 2003, Osugi et al. 2004), the suprachiasmatic nucleus in the frog (Chartrel et al. 2002, Koda et al. 2002, Sawada et al. 2002a) and the nucleus posterior periventricularis in goldfish (Sawada et al. 2002b). The conserved expression of LPXRFamide peptides in hypothalamic neurons (and especially in periventricular regions) suggests an important role of these peptides in neuroendocrine function.

To date, there have been no published reports on the effects of RFRP peptides on feeding, although a lack of effect seems unlikely given the ability of these peptides to bind to the NPFF receptors. Our own studies suggest that both RFRP-1 and -3 have the ability to modify feeding in rats and mice when administered centrally (unpublished observations). ICV administration of RFRP-1 to rats has also been shown to raise circulating levels of prolactin in a concentration-dependent manner, without an observable effect on circulating growth hormone (GH), LH, FSH, thyrotrophin- and adrenocorticotrophin-releasing hormone levels (Hinuma et al. 2000, Samson et al. 2003). However, RFRP-1 was not able to elicit the release of prolactin from dispersed anterior pituitary cells, and its ability to increase prolactin in vivo was attenuated in rats pre-treated with the dopamine D2 receptor blocker, domperidone (Samson et al. 2003). These results suggest that RFRP-1 does not stimulate the release of prolactin directly, but may alter dopamine release into the hypothalamopituitary portal system.

Like NPFF and PrRP, RFRP-1 may be involved in the perception of nociceptive stimuli, as ICV administration of the peptide to rats can block morphine-induced analgesia in acute and inflammatory models of pain (Liu et al. 2001). The occurrence of Rana RFamide-containing fibres in the dorsal horn of the frog spinal cord (Chartrel et al. 2002) suggests that the frog neuropeptide may also be involved in pain modulation. Similarly, an LPXRFamide peptide (nociception-related peptide) in the newt was found to exert an anti-nociceptive effect that was reversed by the opioid-receptor antagonist naloxone (Kanetoh et al. 2003).

\section{Kisspeptin family}

The first of several products of the KiSS gene (referred to collectively as kisspeptins) was purified from tissue extracts of human placenta as a ligand of the orphan receptor, GPR 54. KiSS-1 was identified as a tumour metastasis suppressor gene and the 54 amino acid peptide product was named metastin by virtue of its ability to inhibit migration in different cancer cell types (Lee et al. 1996, Ohtaki et al. 2001).

In the rat brain, three main regions containing metastinimmunoreactive neurons have been identified in the DMN, NTS and the caudal VLM (Brailoiu et al. 2005), although 
immunoreactive fibres exhibit a wide distribution. GPR54, originally cloned from rat brain, shares $45 \%$ identity with galanin receptors, and is widely expressed in the rat central nervous system, including hypothalamus, midbrain, pons, medulla, hippocampus and amygdala (Lee et al. 1999).

Kisspeptin peptides do not appear to alter food intake in either ad libitum-fed or pre-fasted rats (Thompson et al. 2004, Castellano et al. 2005). However, kisspeptin and its putative receptor GPR 54 have been shown to play a pivotal role in the control of gonadotrophin secretion and puberty (de Roux et al. 2003, Seminara et al. 2003). For example, mice in which GPR 54 has been deleted exhibit impaired development of both male and female reproductive systems (Funes et al. 2003). The onset of puberty and sexual maturity depends heavily on sufficient body energy stores, and conditions of negative energy balance can delay puberty and cause reproductive failure. Interestingly, the expression of both KiSS-1 and GPR54 are responsive to feeding status in rats. Specifically, food deprivation of pre-pubertal rats is accompanied by reduced KiSS-1 expression in the hypothalamus and a generalised increase in GPR54 expression (Castellano et al. 2005). In addition, chronic treatment with kisspeptin is able to restore vaginal opening (a sign of reproductive development) and to elicit gonadotrophin and oestrogen responses in undernourished rats (Castellano et al. 2005). Therefore, the responsiveness of hypothalamic KiSS-1 expression to nutritional status might contribute to the suppression of reproductive function in states of negative energy balance.

Non-mammalian homologues of kisspeptin have not yet been identified, although receptors related to GPR103 have been predicted from the chicken genome.

\section{RFa and QRFP}

26RFa and QRFP (from pyroglutamylated RFamide peptide) constitute the most recently identified group of RFamide peptides, having been described by three separate groups in 2003. 26RFa was isolated from brain extracts of the frog Rana esculenta on the basis of its cross-reactivity with an antiserum raised against mammalian NPFF (Chartrel et al. 2003). This peptide was also identified as a high-affinity ligand for the orphan receptor GPR103 in humans and mice (Fukusumi et al. 2003, Jiang et al. 2003). In addition to the 26-amino acid residue, 26RFa, a 43-amino acid residue (QRFP) peptide product was also identified (Fukusumi et al. 2003). Although both 26RFa and QRFP are derived from the same precursor peptide, and both have been shown to be potent ligands of GPR103 (Fukusumi et al. 2003), mass spectrum analyses of brain extracts suggest that QRFP may be the predominant ligand for GPR103, at least in the rat (Takayasu et al. 2006). GPR103 shares significant sequence identity with the NPFF2, neuropeptide Y-Y2 and galanin-R1 receptors (Bonini et al. 2000, Lee et al. 2001).

26RFa QRFP and GPR 103 are expressed in the VMN and the lateral hypothalamus, areas of the brain critically associated with the control of food intake (Chartrel et al. 2003, Fukusumi et al. 2003, Baribault et al. 2006). In fact, in mice, the expression of the peptides is limited almost exclusively to neurons in these two hypothalamic nuclei (Chartrel et al. 2003). In humans, the peptides can be found in PVN and VMN neurons, as well as in the dorsal and the lateral horns of the spinal cord (Bruzzone et al. 2006). Two mouse orthologues of the human GPR103 have now been identified (GPR103A and B) which respond similarly to QRFP, yet exhibit distinct expression patterns within the mouse brain (Takayasu et al. 2006). Specifically, a particularly pronounced expression of GPR103A is localised to the NTS and VMN, while GPR103B is strongly expressed in the PVN, lateral hypothalamus and triangular septal nuclei. Functional differences between the two receptors are not yet known.

In line with its expression in the hypothalamus, acute ICV administration of 26RFa or QRFP in mice stimulates food intake (Chartrel et al. 2003, Moriya et al. 2006, Takayasu et al. 2006), increases locomotor activity (Chartrel et al. 2006, Takayasu et al. 2006) and metabolic rate (Takayasu et al. 2006). Chronic infusion of QRFP over a 2 -week period caused mice to become hyperphagic, and experience significant gains in body weight and fat mass, which was exacerbated when the animals were fed a moderately high-fat diet (Moriya et al. 2006). Interestingly, pair-fed, QRFP-infused mice did not exhibit the increase in body weight but still showed a significant increase in fat mass. In contrast to the elevation in metabolic rate following QRFP administration reported by Moriya et al. (2006), Takayasu et al. (2006) report that both ad libitum- and pair-fed QRFP-infused mice exhibit a significant decrease in rectal temperature and reduced expression of brown adipose tissue uncoupling protein-1 mRNA. Nevertheless, these findings demonstrate that QRFP can modulate both appetite and energy expenditure over a period of chronic exposure.

The orexigenic effect of QRFP does not appear to be diminished in orexin-knockout mice, but is attenuated by the neuropeptide Y-Y1 receptor antagonist BIBP3226, suggesting that QRFP-induced feeding might involve neuropeptide $Y$ signalling (Takayasu et al. 2006). However, it has been proposed that BIBP3226 mimics the RF residues of NPFF-related peptides (neuropeptide Y terminates in RYamide) and binding of the compound to RFamide receptors has been demonstrated previously (Bonini et al. 2000, Gouarderes et al. 2002, Fang et al. 2006, Vyas et al. 2006). In addition to pharmacological evidence showing a role for QRFP and 26RFa in food intake, the expression of mRNA for the QRFP/26RFa precursor, measured using real-time reverse transcription (RT)-PCR of dissected tissues, is elevated in the 'hypothalamic' region of fasted mice, as well as in obese $o b / o b$ and $d b / d b$ mice (Takayasu et al. 2006). Importantly, a study looking at bone formation in GPR103knockout mice reported that body weights are similar between wild-type and knockout littermates, although no data were shown and it was not made clear how the animals were housed or fed (Baribault et al. 2006). 
QRFP has also been reported to have direct effects on aldosterone secretion from rat adrenal gland (Fukusumi $e t$ al. 2003). GPR103, but not QRFP, is abundantly expressed in adrenal gland, suggesting a possible hormonal role for QRFP in releasing this hormone. ICV or systemic injection of $26 \mathrm{RFa}$, or ICV injection of QRFP, increases serum LH levels in cycling and ovariectomised female rats, but not in adult males (Castellano et al. 2005), suggesting a potential involvement for the peptides in energy balance and reproduction in females.

\section{RFamides and invertebrate feeding}

The mechanisms controlling feeding behaviour in mammals and invertebrates obviously differ, nevertheless, the involvement of RFamide peptides in invertebrate feeding provide some interesting parallels. The continuity of feeding-related actions of RFamides between vertebrate and invertebrate suggests either an evolutionary conservation or a convergence of neuropeptide function. It must be acknowledged that RFamides are widely represented in invertebrates and have numerous functions aside from feeding behaviour. In this section, we present a few examples of how RFamide peptides contribute to feeding-related behaviours in invertebrates.

\section{Gastropods}

In snails, feeding requires rhythmic motor patterns to drive the movements of the mouth and pharynx (Chase 2002). On the other hand, escape from aversive stimuli involves withdrawal of the whole body into the shell, which is accomplished by a group of the retractor muscles, collectively known as the columellar muscle (CM; Chase 2002). Interestingly, the contraction of the $\mathrm{CM}$ is strongly influenced by the degree of satiation of the animal (Balaban 2002). Feeding-induced arousal and food intake in snails are regulated to a large extent by serotonergic 5-hydroxytryptamine (5-HT) and dopaminergic neurons (Murphy 2001, Elliott \& Susswein 2002). FMR Famide and FMRFamide-containing pleural neurons both inhibit feeding and facilitate withdrawal behaviour in various gastropod species (Kyriakides \& McCrohan 1989, Murphy 1990, Alania et al. 2004). This is achieved by FMRFamide rapidly attenuating the rhythmic firing of buccal and cerebral ganglion neurons responsible for initiating and maintaining the repetitive motor outputs required for feeding (Alania et al. 2004). In addition, FMRFamide acts directly on muscle groups, such as the pharyngeal retractor muscle (PRM) to antagonise 5-HT signalling and strengthen and prolong contraction (which facilitates withdrawal; Hernadi et al. 2005). A model has been proposed in which pro-feeding signals stimulate repetitive contraction of the PRM in response to 5-HT release, but that when a noxious stimulus is encountered FMRFamide is liberated contributing to a sustained contraction of the PRM and body withdrawal (Hernadi et al. 2005). The balance between FMRFamide and 5-HT responses seems to be partly dependent of the energy status of the animal. Similarly, cholinergic motoneurons innervating the accessory radula closer muscle, are both excited by $5-\mathrm{HT}$ and inhibited by FMRFamide (Sossin et al. 1987).

RFamides within the land snail Cepaea nemoralis also interact with opioid systems to modify nociceptive responsiveness (Tang et al. 1984, Kavaliers et al. 1985, Kavaliers \& Yang 1989). For example, FMRFamide acts antagonistically to endogenous opioids (likely involving downstream serotonergic pathways) in the neuronally controlled switch between passive and active avoidance behaviour (Dyakonova et al. 1995).

\section{Nematodes}

As mentioned above, C. elegans exhibits a large variety of RFamide peptides, with more than 20 RFamide encoding genes (designated $f p-1$ to $f p$-22), and in excess of 50 different peptide products (Li et al. 1999). In addition, a number of GPRs have been identified in the nematode that serve as RFamide receptors, including the neuropeptide receptor-1 (NPR-1), the putative receptor for the peptides FLP-21 and the FMRFamide-like peptide (FLP-18; Kubiak et al. 2003, Rogers et al. 2003). The role of NPR-1 and its ligands in C. elegans behaviour is quite striking, since a single amino acid polymorphism at position 215 of NPR-1 dictates whether the nematodes engage in aggregate or solitary feeding (de Bono \& Bargmann 1998, Rogers et al. 2003). Specifically, a Phe residue at position $215(215 \mathrm{~F})$ on NPR-1 is associated with social feeding, in which animals group together. A Val at this position $(215 \mathrm{~V})$ is associated with solitary feeding, in which the animals spread out over the food source (Fig. 3; de Bono \& Bargmann 1998). Aggregating strains also tend to prefer areas of high food density and show higher rates of locomotion over the food. Activation of NPR-1 inhibits a set of body cavity neurons that themselves normally serve to repress solitary behaviour when food is not present. The sensitivity of NPR-1 to FLP-21 and FLP-18 is higher in the $215 \mathrm{~V}$ variant leading to heightened receptor activity and solitary behaviour in these nematodes (Rogers et al. 2003, Davies et al. 2004).

The manifestation of aggregating behaviour involves multiple pathways, including the nociceptive ASH and ADL neurons. Ablation of these neurons attenuates aggregation of the nematodes, implying that aggregation may be a response to noxious stimuli (de Bono et al. 2002). The induction of solitary behaviour by NPR-1 signalling suggests that its actions may antagonise responses of ASH and ADL to stressful stimuli. FLP-21 is expressed in ASH and ADL neurons (Rogers et al. 2003), suggesting that these neurons can also induce solitary behaviour under certain conditions. Interestingly, the NPR-1 receptor was originally described as a nematode homologue of the vertebrate neuropeptide $\mathrm{Y}$ receptors (de Bono \& Bargmann 1998). Neuropeptide $Y$ is a well-described orexigenic peptide in mammals (Stanley \& Leibowitz 1985), but it has also been linked to nociception (Naveilhan et al. 2001, Li et al. 2002), suggesting that synergistic pathways between feeding behaviour and nociception/stress might have been conserved through natural selection. 


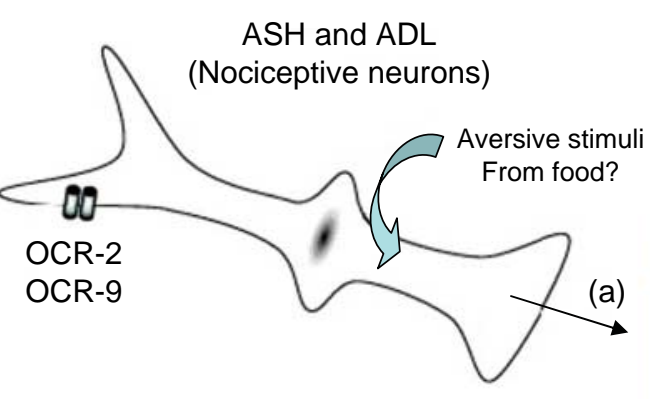

Unidentified neuron

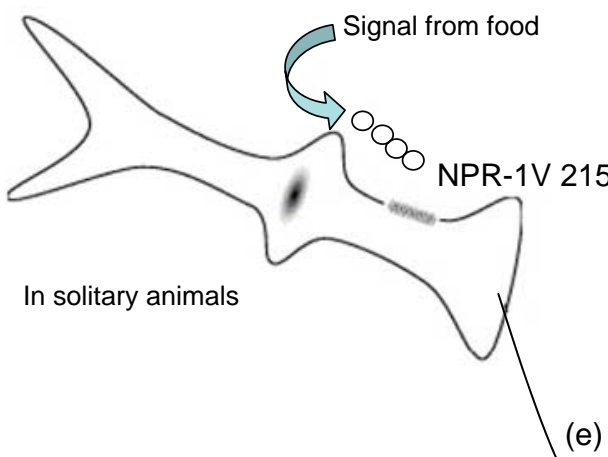

(e)
Aggregate feeding

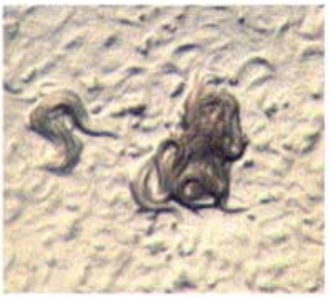

Signal from food

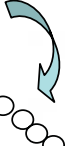

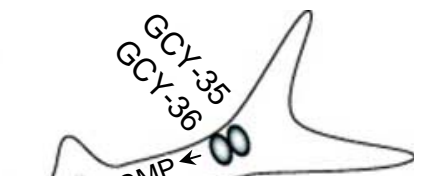

(b)
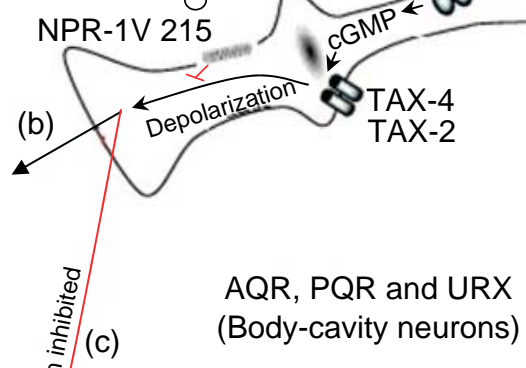

TAX-4

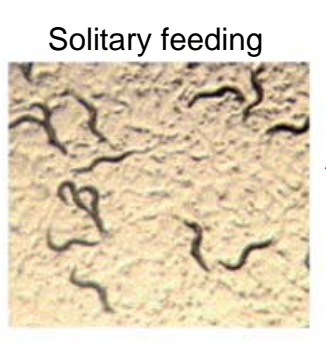

(Body-cavity neurons)

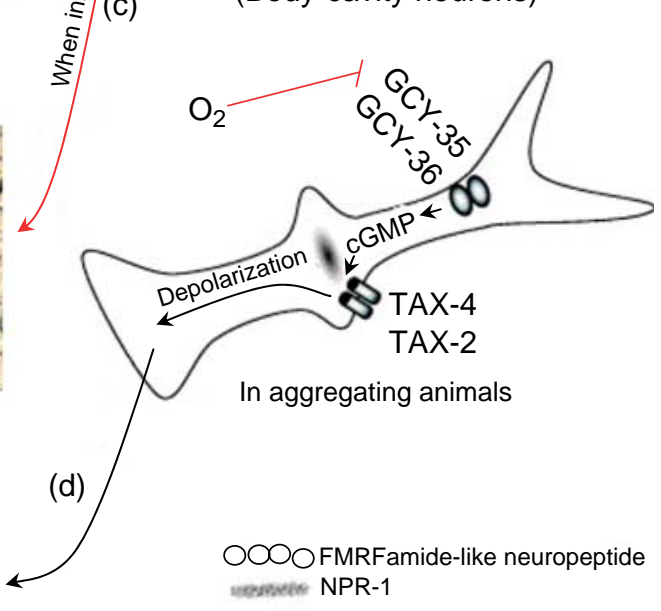

Slowing response on food

Figure 3 A neurogenetic model of food-related behaviours in C. elegans. Arrows represent inductive effects, whereas blunt-ended lines indicate repression. In natural strains the NPR-1 215F isoform is less active and permits aggregation, whereas the NPR-1 215V isoform is more active and represses aggregation. FLP-18 and FLP-21 (FMRFamide-like neuropeptides) are ligands for both isoforms of NPR-1. (a) The chemosensory neurons ASH and ADL mediate nociception and aggregation during feeding. The ocr-2 and osr-9 genes are required for aggregation; they encode transient receptor potential cation channel sub family $\mathrm{V}$ (TRPV) cation channel subunits that form a transduction channel linking sensory input to neuronal activity. In solitary animals, NPR-1 215V signalling suppresses this circuit, possibly by inhibiting sensitivity to nociceptive stimuli (not shown). (b and c) The AQR, PQR and URX body cavity neurons mediate food-dependent aggregation. In solitary animals, this pathway is inhibited by food-dependent signalling through NPR-1 215V (c). (d) Depolarisation of AQR, PQR and URX neurons is also required for locomotory slowing in response to low oxygen levels in aggregating worms, which is also suppressed in solitary animals by NPR-1 215V signalling (not shown). (e) Since food-dependent slowing also occurs in solitary animals, an unidentified, oxygen-independent neural circuit involving the NPR-1 215V form of NPR-1 operates to suppress locomotion in response to food. Figure reproduced from Douglas SJ, Dawson-Scully K \& Sokolowski MB (2005) The neurogenetics and evolution of food-related behaviour. Trends in Neurosciences 28 644-652. Trends in Neuroscience 28; copyright, reproduced with permission from Elsevier.

Insects

Like other animal species, Drosophila melanogaster contains several genes that encode FMRFamide-related peptides (Nichols 2003). FMRFamide immunostaining reveals an extensive network of immunoreactive fibres covering the surface of the crop (Duttlinger et al. 2002) and one of the Drosophila RFamide peptides, dromyosuppression (DMS) has been shown to attenuate crop contractions. In addition, four protein sequences have been identified from the fly as putative neuropeptide Y-like receptors (Hewes \& Taghert 2001), one of which is a receptor for the RFamide, neuropeptide F (NPFA1; Garczynski et al. 2002). Changes in the expression level of NPF-A1 are correlated with gustatory exposure to sugar (Shen
\& Cai 2001). Similarly, both the feeding state (fasted or post meal) and the diet composition influences FMRFamide-like immunoreactivity in the gut tissues of Locusta migratoria (Hill \& Orchard 2005), suggesting that RFamides play a role in maintaining balanced nutrient content in insects.

\section{Conclusions}

The RFamides represent one of the largest and most widespread groups of peptides, having been identified in animals across most classes of the animal kingdom. Further, in a great number of species, RFamides are involved in the regulation of 
feeding behaviour demonstrating a level of conservation through evolution which is rare in neuropeptides. Strangely, the question of whether regulating food intake represents a primary function of RFamide signalling remains. This issue is complicated by the size and diversity of the RFamide family. However, for at least some peptides (such as PrRP in rodents and FLP18/FLP21 in C. elegans) their influence on feeding seems irrefutable. In addition to altering food intake, many RFamides also act on metabolic rate, the other factor in body energy homeostasis. As discussed above, the expression of many RFamides are altered by energy status and therefore may serve to link this status with other physiological (such as reproduction in the case of the kisspeptins) and endocrine systems.

One intriguing evolutionary continuity is the relationship between the RFamide peptides and the nociception and opioid systems. Opioids have a strong influence on feeding and a great deal of evidence links the RFamide peptides to opioid signalling. Under natural conditions, animals have to decide whether to engage in feeding-related behaviours when presented with an attractive food source, a decision made more complicated when the food is available in an environment containing aversive or noxious stimuli. Both physical and emotional stress can have profound effects on feeding, and it is tempting to speculate that RFamide and opioid systems interact to integrate feeding with stress.

\section{Acknowledgements}

We thank the organisers of the 23rd Conference of European Comparative Endocrinologists and the Journal of Endocrinology for the opportunity to present this review. Our work on RFamides has been funded by the Wellcome Trust and the BBSRC. The authors declare that there is no conflict of interest that would prejudice the impartiality of this scientific work.

\section{References}

Alania M, Sakharov DA \& Elliott CJ 2004 Multilevel inhibition of feeding by a peptidergic pleural interneuron in the mollusc Lymnaea stagnalis. Journal of Comparative Physiology A, Neuroethology, Sensory, Neural, and Behavioral Physiology 190 379-390.

Allard M, Labrouche S, Nosjean A \& Laguzzi R 1995 Mechanisms underlying the cardiovascular responses to peripheral administration of NPFF in the rat. Journal of Pharmacology and Experimental Therapeutics 274 577-583.

Arletti R, Benelli A \& Bertolini A 1990 Oxytocin inhibits food and fluid intake in rats. Physiology and Behavior 48 825-830.

Balaban PM 2002 Cellular mechanisms of behavioral plasticity in terrestrial snail. Neuroscience and Biobehavioral Reviews 26 597-630.

Ballet S, Mauborgne A, Gouarderes C, Bourgoin AS, Zajac JM, Hamon M \& Cesselin F 1999 The neuropeptide FF analogue, 1DME, enhances in vivo met-enkephalin release from the rat spinal cord. Neuropharmacology 38 1317-1324.

Baribault H, Danao J, Gupte J, Yang L, Sun B, Richards W \& Tian H 2006 The G-protein-coupled receptor GPR103 regulates bone formation. Molecular and Cellular Biology 26 709-717.

Bechtold DA \& Luckman SM 2006 Prolactin-releasing peptide mediates CCK-induced satiety in mice. Endocrinology 147 4723-4729.
Bentley GE, Perfito N, Ukena K, Tsutsui K \& Wingfield JC 2003 Gonadotropin-inhibitory peptide in song sparrows (Melospiza melodia) in different reproductive conditions, and in house sparrows (Passer domesticus) relative to chicken-gonadotropin-releasing hormone. Journal of Neuroendocrinology 15 794-802.

Boer HH, Schot LP, Veenstra JA \& Reichelt D 1980 Immunocytochemical identification of neural elements in the central nervous systems of a snail, some insects, a fish, and a mammal with an antiserum to the molluscan cardio-excitatory tetrapeptide FMRF-amide. Cell and Tissue Research 213 21-27.

Boersma CJ, Sonnemans MA \& Van Leeuwen FW 1993 Immunocytochemical localization of neuropeptide FF (FMRF amide-like peptide) in the hypothalamo-neurohypophyseal system of Wistar and Brattleboro rats by light and electron microscopy. Journal of Comparative Neurology 336 555-570.

Bonini JA, Jones KA, Adham N, Forray C, Artymyshyn R, Durkin MM, Smith KE, Tamm JA, Boteju LW, Lakhlani PP et al. 2000 Identification and characterization of two $G$ protein-coupled receptors for neuropeptide FF. Journal of Biological Chemistry 275 39324-39331.

de Bono M \& Bargmann CI 1998 Natural variation in a neuropeptide Y receptor homolog modifies social behavior and food response in C. elegans. Cell 94 679-689.

de Bono M, Tobin DM, Davis MW, Avery L \& Bargmann CI 2002 Social feeding in Caenorhabditis elegans is induced by neurons that detect aversive stimuli. Nature 419 899-903.

Brailoiu GC, Dun SL, Ohsawa M, Yin D, Yang J, Chang JK, Brailoiu E \& Dun NJ 2005 KiSS-1 expression and metastin-like immunoreactivity in the rat brain. Journal of Comparative Neurology 481 314-329.

Bruzzone F, Lectez B, Tollemer H, Leprince J, Dujardin C, Rachidi W, Chatenet D, Baroncini M, Beauvillain JC, Vallarino M et al. 2006 Anatomical distribution and biochemical characterization of the novel RFamide peptide $26 \mathrm{RFa}$ in the human hypothalamus and spinal cord. Journal of Neurochemistry 99 616-627.

Castellano JM, Navarro VM, Fernandez-Fernandez R, Nogueiras R, Tovar S, Roa J, Vazquez MJ, Vigo E, Casanueva FF, Aguilar E et al. 2005 Changes in hypothalamic KiSS-1 system and restoration of pubertal activation of the reproductive axis by kisspeptin in undernutrition. Endocrinology 146 3917-3925.

Chartrel N, Dujardin C, Leprince J, Desrues L, Tonon MC, Cellier E, Cosette P, Jouenne T, Simonnet G \& Vaudry H 2002 Isolation, characterization, and distribution of a novel neuropeptide, Rana RFamide (R-RFa), in the brain of the European green frog Rana esculenta. Journal of Comparative Neurology 448 111-127.

Chartrel N, Dujardin C, Anouar Y, Leprince J, Decker A, Clerens S, Do-Rego JC, Vandesande F, Llorens-Cortes C, Costentin J et al. 2003 Identification of $26 \mathrm{RFa}$, a hypothalamic neuropeptide of the RFamide peptide family with orexigenic activity. PNAS $10015247-15252$.

Chartrel N, Bruzzone F, Leprince J, Tollemer H, Anouar Y, Do-Rego JC, Segalas-Milazzo I, Guilhaudis L, Cosette P, Jouenne Tet al. 2006 Structure and functions of the novel hypothalamic RFamide neuropeptides R-RFa and 26RFa in vertebrates. Peptides 27 1110-1120.

Chase R 2002 Behavior and its Neural Control in Gastropod Mollusks., Oxford, New York: Oxford University Press.

Chen C, Dun SL, Dun NJ \& Chang JK 1999 Prolactin-releasing peptideimmunoreactivity in A1 and A2 noradrenergic neurons of the rat medulla. Brain Research 822 276-279.

Chen X, Zidichouski JA, Harris KH \& Jhamandas JH 2000 Synaptic actions of neuropeptide FF in the rat parabrachial nucleus: interactions with opioid receptors. Journal of Comparative Neurology 84 744-751.

Davies AG, Bettinger JC, Thiele TR, Judy ME \& McIntire SL 2004 Natural variation in the $n p r-1$ gene modifies ethanol responses of wild strains of $C$. elegans. Neuron 42 731-743.

Dockray GJ 2004 The expanding family of -RFamide peptides and their effects on feeding behaviour. Experimental Physiology 89 229-235.

Dockray GJ, Vaillant C \& Williams RG 1981 New vertebrate brain-gut peptide related to a molluscan neuropeptide and an opioid peptide. Nature 293 656-657. 
Dockray GJ, Reeve JR Jr, Shively J, Gayton RJ \& Barnard CS 1983 A novel active pentapeptide from chicken brain identified by antibodies to FMRFamide. Nature 305 328-330.

Dong X, Han S, Zylka MJ, Simon MI \& Anderson DJ 2001 A diverse family of GPCRs expressed in specific subsets of nociceptive sensory neurons. Cell 106 619-632.

Douglas SJ, Dawson-Scully K \& Sokolowski MB 2005 The neurogenetics and evolution of food-related behaviour. Trends in Neurosciences 28 644-652.

Duttlinger A, Berry K \& Nichols R 2002 The different effects of three Drosophila melanogaster dFMRFamide-containing peptides on crop contractions suggest these structurally related peptides do not play redundant functions in gut. Peptides 23 1953-1957.

Dyakonova VE, Elofsson R, Carlberg M \& Sakharov DA 1995 Complex avoidance behaviour and its neurochemical regulation in the land snail Cepaea nemoralis. General Pharmacology 26 773-777.

Ellacott KL, Donald EL, Clarkson P, Morten J, Masters D, Brennand J \& Luckman SM 2005 Characterization of a naturally-occurring polymorphism in the UHR-1 gene encoding the putative rat prolactin-releasing peptide receptor. Peptides 26 675-681.

Elliott CJ \& Susswein AJ 2002 Comparative neuroethology of feeding control in molluscs. Journal of Experimental Biology 205 877-896.

Engstrom M, Brandt A, Wurster S, Savola JM \& Panula P 2003 Prolactin releasing peptide has high affinity and efficacy at neuropeptide FF2 receptors. Journal of Pharmacology and Experimental Therapentics 305 825-832.

Fang Q, Guo J, He F, Peng YL, Chang M \& Wang R 2006 In vivo inhibition of neuropeptide FF agonism by BIBP3226, an NPY Y1 receptor antagonist. Peptides 27 2207-2213.

Fujii R, Fukusumi S, Hosoya M, Kawamata Y, Habata Y, Hinuma S, Sekiguchi M, Kitada C, Kurokawa T, Nishimura O et al. 1999 Tissue distribution of prolactin-releasing peptide (PrRP) and its receptor. Regulatory Peptides 83 1-10.

Fukusumi S, Habata Y, Yoshida H, Iijima N, Kawamata Y, Hosoya M, Fujii R, Hinuma S, Kitada C, Shintani Y et al. 2001 Characteristics and distribution of endogenous RFamide-related peptide-1. Biochimica et Biophysica Acta 1540 221-232.

Fukusumi S, Yoshida H, Fujii R, Maruyama M, Komatsu H, Habata Y, Shintani Y, Hinuma S \& Fujino M 2003 A new peptidic ligand and its receptor regulating adrenal function in rats. Journal of Biological Chemistry $27846387-46395$.

Fukusumi S, Fujii R \& Hinuma S 2006 Recent advances in mammalian RFamide peptides: the discovery and functional analyses of PrRP, RFRPs and QRFP. Peptides 27 1073-1086.

Funes S, Hedrick JA, Vassileva G, Markowitz L, Abbondanzo S, Golovko A, Yang S, Monsma FJ \& Gustafson EL 2003 The KiSS-1 receptor GPR54 is essential for the development of the murine reproductive system. Biochemical and Biophysical Research Communications 312 1357-1363.

Furuse M, Tachibana T, Ohgushi A, Ando R, Yoshimatsu T \& Denbow DM 2001 Intracerebroventricular injection of ghrelin and growth hormone releasing factor inhibits food intake in neonatal chicks. Neuroscience Letters 301 123-126.

Garczynski SF, Brown MR, Shen P, Murray TF \& Crim JW 2002 Characterization of a functional neuropeptide F receptor from Drosophila melanogaster. Peptides 23 773-780.

Goncharuk VD, Buijs RM, MacTavish D \& Jhamandas JH 2006 Neuropeptide FF distribution in the human and rat forebrain: a comparative immunohistochemical study. Journal of Comparative Neurology $496572-593$.

Gouarderes C, Tafani JA \& Zajac JM 1998 Affinity of neuropeptide FF analogs to opioid receptors in the rat spinal cord. Peptides 19 727-730.

Gouarderes C, Quelven I, Mollereau C, Mazarguil H, Rice SQ \& Zajac JM 2002 Quantitative autoradiographic distribution of NPFF1 neuropeptide FF receptor in the rat brain and comparison with NPFF2 receptor by using $\left[{ }^{125} \mathrm{I}\right] \mathrm{YVP}$ and $\left[{ }^{125} \mathrm{I}\right] \mathrm{EYF}$ as selective radioligands. Neuroscience $\mathbf{1 1 5}$ 349-361.

Gouarderes C, Faura CC \& Zajac JM 2004a Rodent strain differences in the NPFF1 and NPFF2 receptor distribution and density in the central nervous system. Brain Research 1014 61-70.
Gouarderes C, Puget A \& Zajac JM 2004b Detailed distribution of neuropeptide FF receptors (NPFF1 and NPFF2) in the rat, mouse, octodon, rabbit, guinea pig, and marmoset monkey brains: a comparative autoradiographic study. Synapse 51 249-269.

Grabauskas G, Zhou SY, Das S, Lu Y, Owyang C \& Moises HC 2004 Prolactin-releasing peptide affects gastric motor function in rat by modulating synaptic transmission in the dorsal vagal complex. Journal of Physiology 561 821-839.

Gu W, Geddes BJ, Zhang C, Foley KP \& Stricker-Krongrad A 2004 The prolactin-releasing peptide receptor (GPR10) regulates body weight homeostasis in mice. Journal of Molecular Neuroscience 22 93-103.

Hernadi L, Vehovszky A, Hiripi L, Gyori J, Walker RJ \& Elekes K 2005 Neuroanatomical, immunocytochemical, and physiological studies of the pharyngeal retractor muscle and its putative regulatory neurons playing a role in withdrawal and feeding in the snail, Helix pomatia. Cell and Tissue Research 321 257-271.

Hewes RS \& Taghert PH 2001 Neuropeptides and neuropeptide receptors in the Drosophila melanogaster genome. Genome Research 11 1126-1142.

Hill SR \& Orchard I 2005 In vitro analysis of the digestive enzymes amylase and alpha-glucosidase in the midguts of Locusta migratoria L. in response to the myosuppressin, SchistoFLRFamide. Journal of Insect Physiology 51 1-9.

Hinuma S, Habata Y, Fujii R, Kawamata Y, Hosoya M, Fukusumi S, Kitada C, Masuo Y, Asano T, Matsumoto H et al. 1998 A prolactin-releasing peptide in the brain. Nature 393 272-276.

Hinuma S, Shintani Y, Fukusumi S, Iijima N, Matsumoto Y, Hosoya M, Fujii R, Watanabe T, Kikuchi K, Terao Y et al. 2000 New neuropeptides containing carboxy-terminal RFamide and their receptor in mammals. Nature Cell Biology $2703-708$.

Hizume T, Watanobe H, Yoneda M, Suda T \& Schioth HB 2000 Involvement of prolactin-releasing peptide in the preovulatory luteinizing hormone and prolactin surges in the rat. Biochemical and Biophysical Research Communications 279 35-39.

Ibata Y, Iijima N, Kataoka Y, Kakihara K, Tanaka M, Hosoya M \& Hinuma S 2000 Morphological survey of prolactin-releasing peptide and its receptor with special reference to their functional roles in the brain. Neuroscience Research 38 223-230.

Jhamandas JH \& MacTavish D 2003 Central administration of neuropeptide FF causes activation of oxytocin paraventricular hypothalamic neurones that project to the brainstem. Journal of Neuroendocrinology 15 24-32.

Jhamandas JH, Jhamandas A \& Harris KH 2001 New central projections of neuropeptide FF: colateral branching pathways in the brainstem and hypothalamus in the rat. Journal of Chemical Neuroanatomy 21 171-179.

Jhamandas JH, MacTavish D \& Harris KH 2006 Neuropeptide FF (NPFF) control of magnocellular neurosecretory cells of the rat hypothalamic paraventricular nucleus (PVN). Peptides 27 973-979.

Jiang Y, Luo L, Gustafson EL, Yadav D, Laverty M, Murgolo N, Vassileva G, Zeng M, Laz TM, Behan J et al. 2003 Identification and characterization of a novel RF-amide peptide ligand for orphan G-protein-coupled receptor SP9155. Journal of Biological Chemistry 278 27652-27657.

Kalliomaki ML, Pertovaara A, Brandt A, Wei H, Pietila P, Kalmari J, Xu M, Kalso E \& Panula P 2004 Prolactin-releasing peptide affects pain, allodynia and autonomic reflexes through medullary mechanisms. Neuropharmacology 46 412-424.

Kanetoh T, Sugikawa T, Sasaki I, Muneoka Y, Minakata H, Takabatake I \& Fujimoto M 2003 Identification of a novel frog RFamide and its effect on the latency of the tail-flick response of the newt. Comparative Biochemistry and Physiology. Toxicology and Pharmacology 134 259-266.

Kavaliers M \& Yang HY 1989 IgG from antiserum against endogenous mammalian FMRF-NH2-related peptides augments morphine- and stressinduced analgesia in mice. Peptides 10 741-745.

Kavaliers M, Hirst M \& Mathers A 1985 Inhibitory influences of FMR Famide on morphine- and deprivation-induced feeding. Neuroendocrinology $\mathbf{4 0}$ 533-535.

Kelly SP \& Peter RE 2006 Prolactin-releasing peptide, food intake and hydromineral balance in goldfish. American Journal of Physiology. Regulatory, Integrative and Comparative Physiology. 
Kim K \& Li C 2004 Expression and regulation of an FMRFamide-related neuropeptide gene family in Caenorhabditis elegans. Journal of Comparative Neurology 475 540-550.

Kivipelto L, Majane EA, Yang HY \& Panula P 1989 Immunohistochemical distribution and partial characterization of FLFQPQRFamidelike peptides in the central nervous system of rats. Journal of Comparative Neurology 286 269-287.

Koda A, Ukena K, Teranishi H, Ohta S, Yamamoto K, Kikuyama S \& Tsutsui K 2002 A novel amphibian hypothalamic neuropeptide: isolation, localization, and biological activity. Endocrinology 143 411-419.

Kubiak TM, Larsen MJ, Nulf SC, Zantello MR, Burton KJ, Bowman JW, Modric T \& Lowery DE 2003 Differential activation of 'social' and 'solitary' variants of the Caenorhabditis elegans $\mathrm{G}$ protein-coupled receptor NPR-1 by its cognate ligand AF9. Journal of Biological Chemistry 278 33724-33729.

Kyriakides MA \& McCrohan CR 1989 Effect of putative neuromodulators on rhythmic buccal motor output in Lymnaea stagnalis. Journal of Neurobiology 20 635-650.

Laemmle B, Schindler M, Beilmann M, Hamilton BS, Doods HN \& Wieland HA 2003 Characterization of the NPGP receptor and identification of a novel short mRNA isoform in human hypothalamus. Regulatory Peptides 111 21-29.

Laurent P, Becker JA, Valverde O, Ledent C, de Kerchove DA, Schiffmann SN, Maldonado R, Vassart G \& Parmentier M 2005 The prolactin-releasing peptide antagonizes the opioid system through its receptor GPR10. Nature Neuroscience 8 1735-1741.

Lawrence CB, Celsi F, Brennand J \& Luckman SM 2000 Alternative role for prolactin-releasing peptide in the regulation of food intake. Nature Neuroscience 3 645-646.

Lawrence CB, Ellacott KL \& Luckman SM 2002 PRL-releasing peptide reduces food intake and may mediate satiety signaling. Endocrinology 143 360-367.

Lawrence CB, Liu YL, Stock MJ \& Luckman SM 2004 Anorectic actions of prolactin-releasing peptide are mediated by corticotropin-releasing hormone receptors. American Journal of Physiology. Regulatory, Integrative and Comparative Physiology 286 R101-R107.

Lee CH, Wasowicz K, Brown R, Majane EA, Yang HT \& Panula P 1993 Distribution and characterization of neuropeptide FF-like immunoreactivity in the rat nervous system with a monoclonal antibody. European Journal of Neuroscience 5 1339-1348.

Lee JH, Miele ME, Hicks DJ, Phillips KK, Trent JM, Weissman BE \& Welch DR 1996 KiSS-1, a novel human malignant melanoma metastasis-suppressor gene. Journal of the National Cancer Institute 88 1731-1737.

Lee DK, Nguyen T, O'Neill GP, Cheng R, Liu Y, Howard AD, Coulombe N, Tan CP, Tang-Nguyen AT, George SR \& O'Dowd BF 1999 Discovery of a receptor related to the galanin receptors. FEBS Letter 446 103-107.

Lee Y, Yang SP, Soares MJ \& Voogt JL 2000 Distribution of prolactin-releasing peptide mRNA in the rat brain. Brain Research Bulletin 51 171-176.

Lee DK, Nguyen T, Lynch KR, Cheng R, Vanti WB, Arkhitko O, Lewis T, Evans JF, George SR \& O'Dowd BF 2001 Discovery and mapping of ten novel G protein-coupled receptor genes. Gene 275 83-91.

Li C, Kim K \& Nelson LS 1999 FMRFamide-related neuropeptide gene family in Caenorhabditis elegans. Brain Research 848 26-34.

Li Y, Li JJ \& Yu LC 2002 Anti-nociceptive effect of neuropeptide Y in the nucleus accumbens of rats: an involvement of opioid receptors in the effect. Brain Research 940 69-78.

Liu Q, Guan XM, Martin WJ, McDonald TP, Clements MK, Jiang Q, Zeng Z, Jacobson M, Williams DL Jr, Yu H et al. 2001 Identification and characterization of novel mammalian neuropeptide FF-like peptides that attenuate morphine-induced antinociception. Journal of Biological Chemistry $27636961-36969$.

Luckman SM \& Lawrence CB 2003 Anorectic brainstem peptides: more pieces to the puzzle. Trends in Endocrinology and Metabolism 14 60-65.

Maruyama M, Matsumoto H, Fujiwara K, Kitada C, Hinuma S, Onda H, Fujino M \& Inoue K 1999a Immunocytochemical localization of prolactinreleasing peptide in the rat brain. Endocrinology 140 2326-2333.
Maruyama M, Matsumoto H, Fujiwara K, Noguchi J, Kitada C, Hinuma S, Onda H, Nishimura O, Fujino M, Higuchi T et al. 1999b Central administration of prolactin-releasing peptide stimulates oxytocin release in rats. Neuroscience Letters 276 193-196.

Maruyama M, Matsumoto H, Fujiwara K, Noguchi J, Kitada C, Fujino M \& Inoue K 2001 Prolactin-releasing peptide as a novel stress mediator in the central nervous system. Endocrinology 142 2032-2038.

Matsumoto H, Maruyama M, Noguchi J, Horikoshi Y, Fujiwara K, Kitada C, Hinuma S, Onda H, Nishimura O, Inoue K et al. 2000 Stimulation of corticotropin-releasing hormone-mediated adrenocorticotropin secretion by central administration of prolactin-releasing peptide in rats. Neuroscience Letters 285 234-238.

Mera T, Fujihara H, Kawasaki M, Hashimoto H, Saito T, Shibata M, Saito J, Oka T, Tsuji S \& Onaka T 2006 Prolactin-releasing peptide is a potent mediator of stress responses in the brain through the hypothalamic paraventricular nucleus. Neuroscience 141 1069-1086.

Morales T \& Sawchenko PE 2003 Brainstem prolactin-releasing peptide neurons are sensitive to stress and lactation. Neuroscience 121 771-778.

Moriya R, Sano H, Umeda T, Ito M, Takahashi Y, Matsuda M, Ishihara A, Kanatani A \& Iwaasa H 2006 RFamide peptide QRFP43 causes obesity with hyperphagia and reduced thermogenesis in mice. Endocrinology 147 2916-2922.

Moriyama S, Ito T, Takahashi A, Amano M, Sower SA, Hirano T, Yamamori K \& Kawauchi H 2002 A homolog of mammalian PRL-releasing peptide (fish arginyl-phenylalanyl-amide peptide) is a major hypothalamic peptide of PRL release in teleost fish. Endocrinology 143 2071-2079.

Murase T, Arima H, Kondo K \& Oiso Y 1996 Neuropeptide FF reduces food intake in rats. Peptides 17 353-354.

Murphy AD 1990 An identified pleural ganglion interneuron inhibits patterned motor activity in the buccal ganglia of the snail Helisoma. Brain Research 525 300-303.

Murphy AD 2001 The neuronal basis of feeding in the snail, Helisoma, with comparisons to selected gastropods. Progress in Neurobiology 63 383-408.

Nakazato M, Murakami N, Date Y, Kojima M, Matsuo H, Kangawa K \& Matsukura S 2001 A role for ghrelin in the central regulation of feeding. Nature 409 194-198.

Naveilhan P, Hassani H, Lucas G, Blakeman KH, Hao JX, Xu XJ, WiesenfeldHallin Z, Thoren P \& Ernfors P 2001 Reduced antinociception and plasma extravasation in mice lacking a neuropeptide Y receptor. Nature 409 513-517.

Nichols R 2003 Signaling pathways and physiological functions of Drosophila melanogaster FMRFamide-related peptides. Annual Review of Entomology 48 485-503.

Nicklous DM \& Simansky KJ 2003 Neuropeptide FF exerts pro- and antiopioid actions in the parabrachial nucleus to modulate food intake. American Journal of Physiology. Regulatory, Integrative and Comparative Physiology 285 R1046-R1054.

Ohtaki T, Shintani Y, Honda S, Matsumoto H, Hori A, Kanehashi K, Terao Y, Kumano S, Takatsu Y, Masuda Y et al. 2001 Metastasis suppressor gene KiSS-1 encodes peptide ligand of a G-protein-coupled receptor. Nature $\mathbf{4 1 1}$ 613-617.

Okuno S, Watanabe TK, Ono T, Oga K, Mizoguchi-Miyakita A, Yamasaki Y, Goto Y, Shinomiya H, Momota H, Miyao H et al. 2001 Effects of Dmo1 on obesity, dyslipidaemia and hyperglycaemia in the Otsuka Long Evans Tokushima Fatty strain. Genetical Research 77 183-190.

Olson BR, Drutarosky MD, Chow MS, Hruby VJ, Stricker EM \& Verbalis JG 1991 Oxytocin and an oxytocin agonist administered centrally decrease food intake in rats. Peptides 12 113-118.

Osugi T, Ukena K, Bentley GE, O’Brien S, Moore IT, Wingfield JC \& Tsutsui K 2004 Gonadotropin-inhibitory hormone in Gambel's whitecrowned sparrow (Zonotrichia leucophrys gambelii): cDNA identification, transcript localization and functional effects in laboratory and field experiments. Journal of Endocrinology 182 33-42.

Osugi T, Ukena K, Sower SA, Kawauchi H \& Tsutsui K 2006 Evolutionary origin and divergence of PQRFamide peptides and LPXRFamide peptides in the RFamide peptide family. Insights from novel lamprey RFamide peptides. FEBS Journal 273 1731-1743. 
Panula P, Kalso E, Nieminen M, Kontinen VK, Brandt A \& Pertovaara A 1999 Neuropeptide FF and modulation of pain. Brain Research 848 191-196.

Perry SJ, Yi-Kung HE, Cronk D, Bagust J, Sharma R, Walker RJ, Wilson S \& Burke JF 1997 A human gene encoding morphine modulating peptides related to NPFF and FMRFamide. FEBS Letters 409 426-430.

Price DA \& Greenberg MJ 1977 Purification and characterization of a cardioexcitatory neuropeptide from the central ganglia of a bivalve mollusc. Preparative Biochemistry 7 261-281.

Raffa RB, Kim A, Rice KC, de Costa BR, Codd EE \& Rothman RB 1994 Low affinity of FMRFamide and four FaRPs (FMRFamide-related peptides), including the mammalian-derived FaRPs F-8-Famide (NPFF) and A-18-Famide, for opioid mu, delta, kappa 1, kappa 2a, or kappa $2 \mathrm{~b}$ receptors. Peptides 15 401-404.

Rogers C, Reale V, Kim K, Chatwin H, Li C, Evans P \& de Bono M 2003 Inhibition of Caenorhabditis elegans social feeding by FMRFamide-related peptide activation of NPR-1. Nature Neuroscience 6 1178-1185.

Roland BL, Sutton SW, Wilson SJ, Luo L, Pyati J, Huvar R, Erlander MG \& Lovenberg TW 1999 Anatomical distribution of prolactin-releasing peptide and its receptor suggests additional functions in the central nervous system and periphery. Endocrinology 140 5736-5745.

de Roux N, Genin E, Carel JC, Matsuda F, Chaussain JL \& Milgrom E 2003 Hypogonadotropic hypogonadism due to loss of function of the KiSS1derived peptide receptor GPR54. PNAS 100 10972-10976.

Samson WK, Keown C, Samson CK, Samson HW, Lane B, Baker JR \& Taylor MM 2003 Prolactin-releasing peptide and its homolog RFRP-1 act in hypothalamus but not in anterior pituitary gland to stimulate stress hormone secretion. Endocrine 20 59-66.

Saper CB 2004 Central autonomic system. In The Rat Nervous System, 3 , pp 761-794. Ed. G Paxinos. San Diego, CA: Elsevier Academic Press.

Sawada K, Ukena K, Kikuyama S \& Tsutsui K 2002a Identification of a cDNA encoding a novel amphibian growth hormone-releasing peptide and localization of its transcript. Journal of Endocrinology 174 395-402.

Sawada K, Ukena K, Satake H, Iwakoshi E, Minakata H \& Tsutsui K $2002 b$ Novel fish hypothalamic neuropeptide. European Journal of Biochemistry 269 6000-6008.

Schwartz MW, Woods SC, Porte D Jr, Seeley RJ \& Baskin DG 2000 Central nervous system control of food intake. Nature 404 661-671.

Seale AP, Itoh T, Moriyama S, Takahashi A, Kawauchi H, Sakamoto T, Fujimoto M, Riley LG, Hirano T \& Grau EG 2002 Isolation and characterization of a homologue of mammalian prolactin-releasing peptide from the tilapia brain and its effect on prolactin release from the tilapia pituitary. General and Comparative Endocrinology 125 328-339.

Seminara SB, Messager S, Chatzidaki EE, Thresher RR, Acierno JS Jr, Shagoury JK, Bo-Abbas Y, Kuohung W, Schwinof KM, Hendrick AG et al. 2003 The GPR 54 gene as a regulator of puberty. New England Journal of Medicine 349 1614-1627.

Shen P \& Cai HN 2001 Drosophila neuropeptide F mediates integration of chemosensory stimulation and conditioning of the nervous system by food. Journal of Neurobiology 47 16-25.

Sossin WS, Kirk MD \& Scheller RH 1987 Peptidergic modulation of neuronal circuitry controlling feeding in Aplysia. Journal of Neuroscience 7 671-681.

Stanley BG \& Leibowitz SF 1985 Neuropeptide Y injected in the paraventricular hypothalamus: a powerful stimulant of feeding behavior PNAS 82 3940-3943.

Sun B, Fujiwara K, Adachi S \& Inoue K 2005 Physiological roles of prolactinreleasing peptide. Regulatory Peptides 126 27-33.

Sunter D, Hewson AK, Lynam S \& Dickson SL 2001 Intracerebroventricular injection of neuropeptide FF, an opioid modulating neuropeptide, acutely reduces food intake and stimulates water intake in the rat. Neuroscience Letters 313 145-148.
Tachibana T, Saito S, Tomonaga S, Takagi T, Saito ES, Nakanishi T, Koutoku T, Tsukada A, Ohkubo T, Boswell Tet al. 2004 Effect of central administration of prolactin-releasing peptide on feeding in chicks. Physiology and Behavior $\mathbf{8 0}$ 713-719.

Tachibana T, Tsukada A, Fujimoto M, Takahashi H, Ohkubo T, Boswell T \& Furuse M 2005 Comparison of mammalian prolactin-releasing peptide and Carassius RFamide for feeding behavior and prolactin secretion in chicks. General and Comparative Endocrinology 144 264-269.

Takayasu S, Sakurai T, Iwasaki S, Teranishi H, Yamanaka A, Williams SC, Iguchi H, Kawasawa YI, Ikeda Y, Sakakibara I et al. 2006 A neuropeptide ligand of the $\mathrm{G}$ protein-coupled receptor GPR103 regulates feeding, behavioral arousal, and blood pressure in mice. PNAS 103 7438-7443

Tang J, Yang HY \& Costa E 1984 Inhibition of spontaneous and opiatemodified nociception by an endogenous neuropeptide with Phe-Met-ArgPhe-NH2-like immunoreactivity. PNAS 81 5002-5005.

Taylor MM \& Samson WK 2001 The prolactin releasing peptides: RF-amide peptides. Cellular and Molecular Life Sciences 58 1206-1215.

Thompson EL, Patterson M, Murphy KG, Smith KL, Dhillo WS, Todd JF, Ghatei MA \& Bloom SR 2004 Central and peripheral administration of kisspeptin-10 stimulates the hypothalamic-pituitary-gonadal axis. Journal of Neuroendocrinology 16 850-858.

Tsutsui K, Saigoh E, Ukena K, Teranishi H, Fujisawa Y, Kikuchi M, Ishii S \& Sharp PJ 2000 A novel avian hypothalamic peptide inhibiting gonadotropin release. Biochemical and Biophysical Research Communications 275 661-667.

Ukena K \& Tsutsui K 2001 Distribution of novel RFamide-related peptidelike immunoreactivity in the mouse central nervous system. Neuroscience Letters 300 153-156.

Vaccarino FJ, Bloom FE, Rivier J, Vale W \& Koob GF 1985 Stimulation of food intake in rats by centrally administered hypothalamic growth hormone-releasing factor. Nature 314 167-168.

Vilim FS, Aarnisalo AA, Nieminen ML, Lintunen M, Karlstedt K, Kontinen VK, Kalso E, States B, Panula P \& Ziff E 1999 Gene for pain modulatory neuropeptide NPFF: induction in spinal cord by noxious stimuli. Molecular Pharmacology 55 804-811.

Vyas N, Mollereau C, Cheve G \& McCurdy CR 2006 Structure-activity relationships of neuropeptide $\mathrm{FF}$ and related peptidic and non-peptidic derivatives. Peptides 27 990-996.

Watanabe TK, Okuno S, Yamasaki Y, Ono T, Oga K, Mizoguchi-Miyakita A, Miyao H, Suzuki M, Momota H, Goto Y et al. $2004 \mathrm{~A}<1.7 \mathrm{cM}$ interval is responsible for Dmo1 obesity phenotypes in OLETF rats. Clinical and Experimental Pharmacology and Physiology 31 110-112.

Watanabe TK, Suzuki M, Yamasaki Y, Okuno S, Hishigaki H, Ono T, Oga K, Mizoguchi-Miyakita A, Tsuji A, Kanemoto N et al. 2005 Mutated G-protein-coupled receptor GPR10 is responsible for the hyperphagia/dyslipidaemia/obesity locus of Dmo1 in the OLETF rat. Clinical and Experimental Pharmacology and Physiology 32 355-366.

Weber E, Evans CJ, Samuelsson SJ \& Barchas JD 1981 Novel peptide neuronal system in rat brain and pituitary. Science 214 1248-1251.

Yang HY, Tang J, Iadarola M, Panula P \& Costa E 1985 Are Phe-Met-ArgPhe-NH2 immunoreactive peptides endacoids modulating opiate antinociception? Progress in Clinical and Biological Research 192 313-322.

Yano T, Iijima N, Kakihara K, Hinuma S, Tanaka M \& Ibata Y 2003 Localization and neuronal response of RFamide related peptides in the rat central nervous system. Brain Research 982 156-167.

Yoshida H, Habata Y, Hosoya M, Kawamata Y, Kitada C \& Hinuma S 2003 Molecular properties of endogenous RFamide-related peptide-3 and its interaction with receptors. Biochimica et Biophysica Acta 1593 151-157.

\section{Received in final form 20 October 2006 Accepted 26 October 2006 Made available online as an Accepted Preprint 30 October 2006}

